\title{
PEMBERDAYAAN MASYARAKAT SEBAGAI TEROBOSAN DALAM BERWIRAUSAHA UNTUK MEMANFAATKAN SUMBER DAYA ALAM
}

\author{
Destiana Mentari dan mahasiswa KKN Reguler devisi XIII.D \\ Universitas Ahmad Dahlan Yogyakarta \\ E-mail: Destiana1302001221@webmail.uad.ac.id
}

\begin{abstract}
Abstrak
Salah satu permasalahan yang ada di masyarakat Dusun Tanjung, Desa Temuwuh, Kecamatan Dlingo Kabupaten Bantul adalah banyaknya wirausaha yang masih sulit dalam memasarkan produk usahanya. Maka program KKN UAD difokuskan pada usaha mandiri bagi wirausaha. Program ini bertujuan sebagai pemberdayaan terarah bagi wirausaha yang mayoritas dimasyarakat temuwuh ini adalah pengrajin kayu. Metode pelaksanaan program KKN dalam pemberdayaan masyarakat ini meliputi: pemberdayaan masyarakat, pengenalan berwirausaha mandiri, dari kegiatan KKN ini adalah: 1) tercipta kesadaran masyarakat dalam pentingnya berwirausaha 2) peningkatan pengetahuan masyarakat dalam berwirausaha, 3) masyarakat mampu menjalankan usaha dengan terampil.
\end{abstract}

Kata kunci: pemberdayaan, wirausaha, pengetahuan kewirausahaan.

\begin{abstract}
One of the problems faced bythe society of Tanjung Sub Village, Temuwuh Village, Dlingo Sub Ditrict, BantulRegency is lots of entrepreneur who has difficultiesin their products. Thus, UAD Student Community Service Regular Program (KKN) focused on independent business for entrepreneur. This program is aimedat empowering entrepreneurs in this Sub Village that most of them are craftsmen. Methods of implementation of this KKN program include: community empowerment, independent entrepreneurship introduction, and from this program: 1) the emergence of the community awareness of the importance of entrepreneurship; 2) community knowledge improvement in entrepreneurship; and 3) the community can run their business skillfully.

Key words: Empowerment, entrepreneurship, entrepreneurship knowledge.
\end{abstract}

\section{A. PENDAHULUAN}

Tanjung yang merupakan salah satu Dusun di kelurahan Temuwuh. Jarak Dusun Tanjung dari Desa Temuwuh ini $1 \mathrm{~km}$. Dusun Tanjung memiliki RT sebanyak 4. Potensi Sumber Daya Alam yang terdapat di Dusun Tanjung ini yakni berupa pertanian, kehutanan, perkebunan dan peternakan. Akses jalan Dusun sebagian beraspal dan sebagian jalan cor blok.. Keadaan tanah pada Dusun Tanjung adalah subur dan air cukup memadai yang berasal dari PDAM. Mayoritas masyarakat Dusun Tanjung ini berprofesi sebagai pengrajin kayu, petani, pedagang, dan karyawan swasta. Beberapa permasalahan yang ditemukan di Dusun Tanjung adalah : 1). Rendahnya pendidikan, mengingat pendidikan di zaman yang sekarang ini sangat dibutuhkan karena semakin ketatnya persaingan terutama dalam dunia pekerjaan, 2). Faktor ekonomi karena kurangnya minat dan keterampilan warga. 
Tantangan untuk mewujudkan kemandirian dan ketahanan pangan makin besar seiring dengan menurunnya luas lahan subur dan produktif di Jawa akibat alih fungsi lahan untuk pemukiman dan industri, serta menurunnya daya dukung infrastruktur pertanian. Dalam menghadapi tantangan tersebut, diperlukan berbagai langkah terobosan dalam berwirausaha, mulai dari peningkatan produksi bagi masyarakat yang berwirausaha.

Tujuan ini akan dapat memberikan nilai tambah terhadap produk yang dihasilkan oleh wirausaha, baik secara ekonomi maupun secara kegunaan. Dan meningkatnya pengetahuan masyarakat tentang kewirausahaan dan usaha mandiri. Indonesia memiliki beragam hasil alam yang diolah dan berpotensi sebagai sumber penghasilan alternatif dan perlu dikembangkan yang mendukung. Dengan berkembangnya produk usaha maka jumlah dan jenis produk yang dihasilkan menjadi semakin beragam.

Kemampuan kreatif dan inovatif yang dijadikan dasar, kiat dan sumber daya untuk mencari peluang menuju sukses. Inti dari kewirausahaan adalah kemampuan untuk menciptakan sesuatu yang baru dan berbeda (create new and different) melalui berfikir kreatif dan inovatif. (Suryana, 2003). Adapun kewirausahaan merupakan sikap mental dan sifat jiwa yang selalu aktif dalam berusaha untuk memajukan karya baktinya dalam rangka upaya meningkatkan pendapatan di dalam kegiatan usahanya. Selain itu kewirausahan adalah kemampuan kreatif dan inovatif yang dijadikan dasar, kiat, dan sumber daya untuk mencari peluang menuju sukses. Akan tetapi pada kenyataannya masalah yang dihadapi oleh sebagian masyarakat di Dusun Tanjung adalah banyakanya persaingan dalam berwirausaha, dan kurangnya pengetahuan untuk memanfaatkan sumber daya alam yang ada disekitar dalam pengembangan sebuah produk baru yang menghasilkan nilai rupiah.

Berdasarkan permasalahan tersebut, maka ditetapkan tujuan program KKN ini adalah pemberdayaan masyarakat dalam berwirausaha.

\section{B. METODE PELAKSANAAN}

Untuk mencapai tujuan yang diharapkan, program KKN di Dusun Tanjung dilakukan dengan pemberdayaan masyarakat melalui talkshow kewirausahaan. Pengadaan pelatihan langsung produk usaha, Ringkasan metode pelaksanaan beserta jam kerja efektif mahasiswa (JKEM) tersaji pada tabel I. 
Tabel I. Metode, Kegiatan, JKEM dan keterlibatan mahasiswa

\begin{tabular}{|c|c|c|c|c|}
\hline No & Metode & Kegiatan & JKEM & $\begin{array}{l}\text { Jumlah } \\
\text { mahasiswa } \\
\text { yang terlibat }\end{array}$ \\
\hline 1 & $\begin{array}{l}\text { Penyelengaraan } \\
\text { talkshow } \\
\text { kewirausahaan }\end{array}$ & $\begin{array}{l}\text { Menyelenggarakan talkshow } \\
\text { kewirausahaan di kelurahan } \\
\text { temuwuh. }\end{array}$ & 1 x 300” & 27 \\
\hline \multirow[t]{9}{*}{2} & \multirow{9}{*}{$\begin{array}{l}\text { Pengadaan } \\
\text { pelatihan } \\
\text { langsung produk } \\
\text { usaha }\end{array}$} & $\begin{array}{l}\text { Menyelenggarakan pelatihan } \\
\text { pembuatan makanan dari } \\
\text { tepung mocaf }\end{array}$ & $1 \times 300 "$ & 27 \\
\hline & & $\begin{array}{l}\text { Penyelenggaraan pelatihan } \\
\text { bunga dari kulit jagung }\end{array}$ & $2 \times 100 "$ & 27 \\
\hline & & $\begin{array}{l}\text { Penyelenggaraan pelatihan } \\
\text { pengolahan limbah kayu }\end{array}$ & 1 x $150 "$ & 27 \\
\hline & & $\begin{array}{l}\text { Penyelenggaraan pelatihan } \\
\text { pengolahan daging ayam }\end{array}$ & $1 \times 200 "$ & 27 \\
\hline & & $\begin{array}{l}\text { Pelatihan pengolahan bahan } \\
\text { local berupa tempe }\end{array}$ & $1 \times 250 "$ & 3 \\
\hline & & $\begin{array}{l}\text { Penyelenggaraan pelatihan } \\
\text { pengolahan bubuk jahe }\end{array}$ & $1 \times 250 "$ & 27 \\
\hline & & $\begin{array}{l}\text { Penyelenggaraan pelatihan } \\
\text { pengolahan sirup jahe }\end{array}$ & $4 \times 100 "$ & 3 \\
\hline & & $\begin{array}{l}\text { Pelatihan Pembuatan sicogan } \\
\text { (singkong coklat elegan) }\end{array}$ & 4 x 100" & 3 \\
\hline & & $\begin{array}{l}\text { Pelatihan pembuatan kerupuk } \\
\text { basah lele }\end{array}$ & 4 x 100” & 3 \\
\hline
\end{tabular}

\section{HASIL, PEMBAHASAN DAN DAMPAK}

\section{Profil Desa}

Dusun Tanjung adalah salah satu dusun yang berada didesa Temuwuh, Kecamatan Dlingo, Kabupaten Bantul, Daerah istimewa Yogyakarta. Dusun ini terletak di sebelah timur pusat Kota Yogyakarta dengan jarak sekitar 25 km. Luwas wilayah Dusun Tanjung Mencapai 766.3545 Ha. Jika dilihat dari titk koordinat geografi, Dusun Tanjung verada digaris 755'23'5'S 100. Sebelah utara berbatasan dengan Dusun Nglampengan, Sebelah timur berbatasan dengan Dusun Jambewangi, Sebelah barat dengan Dusun Jurug, Sebelah Selatan berbatasan dengan Dusun Tekik. 
Diterbitkan oleh Lembaga Pengabdian kepada Masyarakat

Universitas Ahmad Dahlan Yogyakarta

\section{Gambaran Pelaksanaan}

Gambar aktivitas mahasiswa KKN UAD dan masyarakat Dusun Tanjung dalam program talkshow kewirausahaan gambar 1.

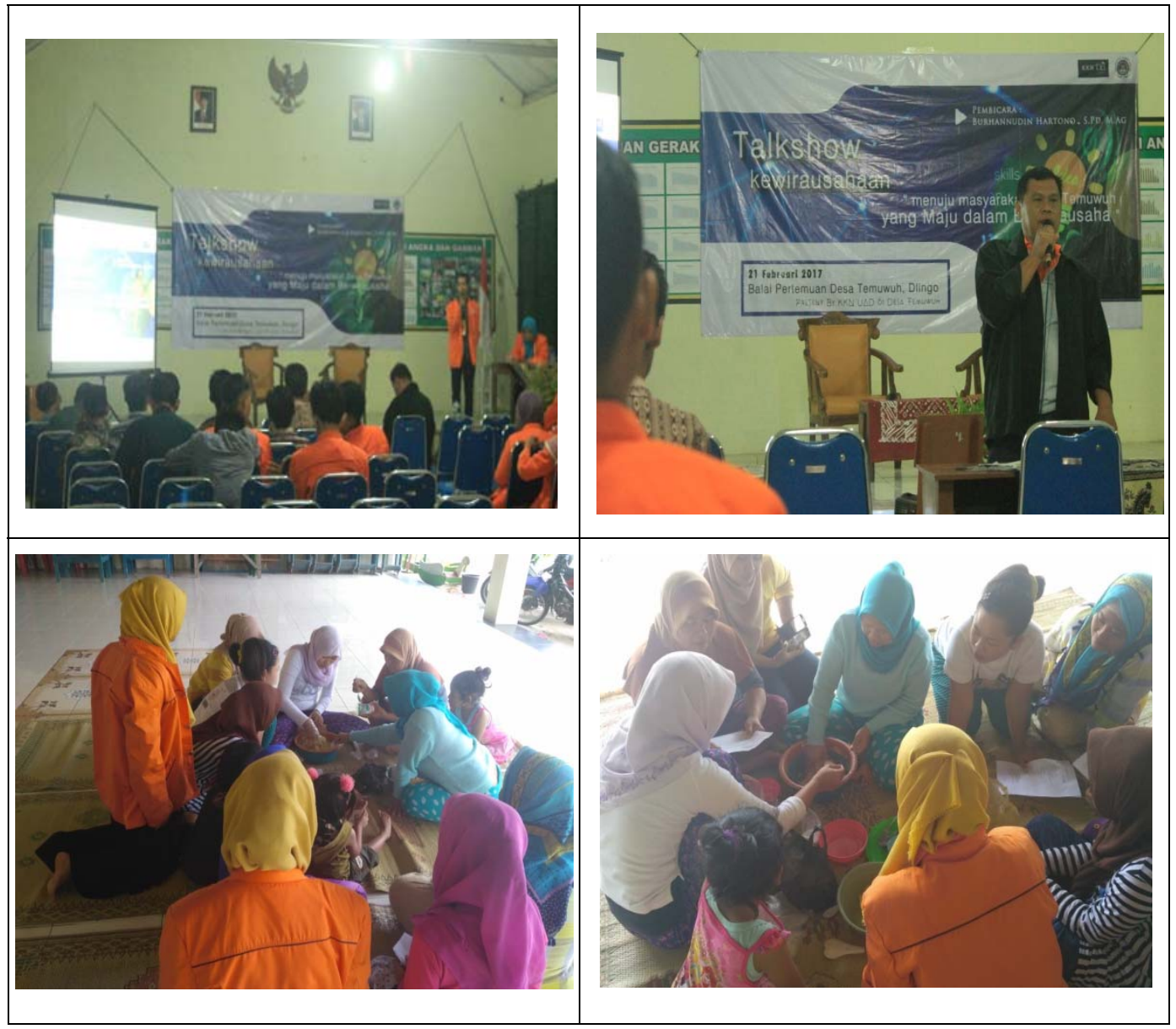

Gambar 1. Aktivitas mahasiswa KKN UAD dan masyarakat Dusun Tanjung dalam berpartisipasi mengikuti pelatihan mengolah sumber daya alam.

Dari gambar 1 terlihat program KKN di Dusun Tanjung dapat terlaksana dengan partisipasi masyarakat yang cukup tinggi dengan kata lain dapat dalam pemberdayaan masyarakat dalam program-program yang telah direncanakan. Dampak dari kegiatan KKN ini adalah: 1) tercipta kesadaran masyarakat dalam pentingnya berwirausaha 2) peningkatan pengetahuan masyarakat dalam berwirausaha, 3) masyarakat mampu menjalankan usaha dengan terampil.

\section{KESIMPULAN}

Program KKN UAD dalam pemberdayaan masyarakat Dusun Tanjung dalam berwirausaha dengan pemberdayaan masyarakat melalui talkshow kewirausahaan pengadaan pelatihan produk usaha yang meliputi pelatihan pengolahan limbah kayu , pelatihan pembuatan makanan dari tepung mocaf yakni pisang coklat dan martabak telur, pelatihan pembuatan bunga dari kulit jagung, pelatihan pengolahan limbah kayu, pelatihan 
pengolahan daging ayam, pelatihan membuat sirup jahe, pelatihan pembuatan sicogan (singkong coklat elegan), pelatihan pembuatan kerupuk basah lele, pelatihan pembuatan martabak manis.

Peserta pelatihan sangat antusias dalam berpartisipasi mengikuti kegiatan ini. Harapan kami adanya pelatihan yang kami selenggarakan dapat meningkatkan motivasi, inovasi, dan kreatifitas masyarakat Dusun Tanjung dalam berwirausaha.

\section{DAFTAR PUSTAKA}

Dr. Suryana, M.Si. (2008). Kewirausahaan: Pedoman Praktis: Kiat dan Proses Menuju Sukses. (cetakan ketiga). Jakarta. Penerbit Salemba Empat.

“Anonim”. 2009. Kewirausahaan. diambil dari http://kewirausahaan-kang_amin.com. Pada tangaal 5 Maret 2017 